ISSN 2414-1143

Научный альманах стран Причерноморья. 2018. Том 15. № 3

DOI 10.23947/2414-1143-2018-15-3-3-10

UDC 1:316+008

\title{
THE INTERACTION OF LEVELS OF HISTORICAL CONSCIOUSNESS IN THE CONTEXT OF THE CULTURE OF NATIONAL SECURITY
}

\author{
(C) Yuri A. Shestakov
}

\author{
Don State Technical University \\ Rostov-on-Don, Russian Federation \\ shesyur@mail.ru
}

The article analyzes the interaction of the levels of historical consciousness in the context of the formation of the culture of national security. The structure of historical consciousness as a special kind of social consciousness usually includes two main levels: scientific (theoretical, ideological) and ordinary (empirical, psychological and emotional). It is stated that the historical science and philosophy of history are conditioned by the General cultural determinants of mass historical consciousness, which make up the matrix of historical memory and "grow" primarily on the basis of the ordinary level of historical consciousness. The advantage of the mythologized ordinary level of historical consciousness is that it allows to transfer moral imperatives, which are guided by the national-state community, which is the essence of its cultural identity, from the sphere of the present limited by the various conditions of cash by "rooting" in history to the aspect of due. On the other hand, bearing in mind the inter-interests of national security, it is necessary to strengthen the role of historical science and philosophy of history in the fight against non cultural manifestations of historical consciousness, which are based, or rather parasitize, on such a fundamental characteristic of the empirical, ordinary, socio-psychological level of historical consciousness as mythologization. The danger of uncontrolled mythologization of historical consciousness is that society, under the influence of overly emphasized by the myth of emotional and evaluative components (including a variety of phobias and stereotypes), can succumb either to the temptations of the present archaization or modernization of the past. The thesis that it is the theoretical, scientific level of historical consciousness that plays a leading role in the formation of national consciousness is sufficiently justified, since the formation of the nation is associated with the modernization processes, with the formation of the foundations of industrial society as a stage of development of the world historical process, unthinkable without the leading, "cultural" role of science in the spiritual sphere of society in relation to ordinary social consciousness. It seems reasonable that the ways to solve the urgent problem of formation of the historical consciousness that meets the modern requirements of national security culture, alien to both cultural refinement (the formation of which is associated with the downplaying of the role of the ordinary level of historical consciousness), and falsification on the basis of destructive mythologization (associated with the minimization of the role of its theoretical level), are to promote historical science, philosophical and historical knowledge by means of living, everyday language, as well as in the institutionalization of this process.

Keywords: historical consciousness, socio-psychological level, theoretical level, culture, national security, archaization, modernization, falsification

\section{[Ю.А. Шестаков Взаимодействие уровней исторического сознания в контексте формирования культуры национальной безопасности]}

Анализируются уровни исторического сознания, культуры национальной безопасности, их взаимовлияние и взаимообусловленность. Подчеркивается, что структура исторического сознания в качестве особого рода феномена включает в себя два основных уровня: научный (теоретический, идеологический) и обыденный (эмпирический, психолого-эмоциональный). Выявляется обусловленность исторической науки и философии истории общекультурными детерминантами массового исторического сознания, составляющими матрицу исторической памяти и «вырастающими» на основе обыденного уровня исторического сознания. Преимущество мифологизированного исторического сознания заключается в том, что оно позволяет перевести моральные императивы, которыми руководствуется национально-государственное сообщество, составляющее сущность его культурного своеобразия, из сферы, ограниченной наличными условиями настоящего, в аспект должного. Вместе с тем интересы обеспечения национальной безопасности требуют усиления роли науки в борьбе с акультурными проявлениями исторического сознания, которые базируются на такой характеристике эмпирического уровня исторического сознания как мифологичность. Выявлена опасность неконтро- 
лируемой мифологизации исторического сознания, состоящая в том, что общество, под влиянием чрезмерно акцентуируемых мифом эмоционально-оценочных компонентов (в том числе разнообразных фобий и стереотипов), может поддаваться либо соблазнам архаизации настоящего, либо модернизации прошлого. Обоснован тезис о том, что формирование нации связано с модернизационными процессами, с созданием основ индустриального общества как ступени развития мирового исторического процесса, немыслимого без «окультуривающей» роли науки в духовной сфере жизни общества. Доказано, что решение проблемы формирования, отвечающего современным требованиям культуры национальной безопасности исторического сознания, чуждого как культурной рафинированности, так и фальсификации на основе деструктивной мифологизации, заключаются в популяризации исторической науки, философско-исторического знания, а также в институционализации этого процесса.

Ключевые слова: историческое сознание, социально-психологический уровень, теоретический уровень, культура, национальная безопасность, архаизация, модернизация, фальсификация.

Yuri A. Shestakov - candidate of history, associate professor. Don State Technical University. Rostov region, Shakhty, Russian Federation.

Шестаков Юрий Александрович - кандидат исторических наук, доцент. Донской государственный технический университет. Ростовская область, г. Шахты, Россия.

Because of the need for national security ensuring the cultural and philosophical thought of modernity actively turns to the problem of formation of national security culture as to a valuable basis of realization of the fundamental interests of national and state community. Since these interests, as well as the ways of their realization, were formed in the course of the historical development of the national and state community and for this nation they have been particularly reflected in historical consciousness of the bearer of sovereignty, it is represented that cognition and consequently preservation and development of the main determinants of national security are impossible beyond historical consciousness. Above all, this is a transhistorical valuable and semantic nature of civilization to which the nation, originality of relationships between individual, society and state in its frames, cultural and specific originality of national security formation, etc. identify themselves. The problem of formation of historical consciousness relevant to challenges, risks and threats of modernity «allowing to make the most optimal decisions at present and to carry out goal-setting appropriate to the nation existence sense regarding the future" [15, p. 58] is especially relevant for our Fatherland. The transitive nature of modern Russian national and state community and situation of the deep socio-cultural crisis together with such fundamental characteristic of postmodern culture as "loss of historicity" [9, p. 194] substantiate its decision as the first priority for preservation and development of spiritual independence of nation representing the inner core which provides preservation of political and economic sovereignty. As the analysis of phenomenon structure for the purpose of clarification of its possible development prospects is the main method of any scientific and philosophical research, clarification of correlation of historical consciousness levels in the context of formation of national security culture is relevant.

According to modern researches, the structure of historical consciousness as a special kind of social consciousness includes two main levels: ordinary (empirical, psychological and emotional) and scientific (theoretical, ideological). These levels of historical consciousness reproduce the society culture. As a result, historical consciousness represents "... the fundamental world outlook characteristic of culture of any epoch" [7, p. 143-145] as culture is formed by history and forms historical process. At the same time, interpretation by historical consciousness of historical phenomena is culturally predetermined and culturally issued. In other words, "... our vision and understanding of the past is caused by any cultural forms" [11, p. 186]. 
In this respect, the distinction between theoretical and empirical levels of historical consciousness, historical psychology and historical ideology is unimportant - all of them are generation of a single cultural context focused on explanation of the present and the embodiment in the future of definite purposes and ideals. Ways of historical process understanding are culturally determined. This cultural determination is caused by a valuable and semantic core of civilization. Historical consciousness, in fact, represents a view of historical process through the prism of meta-historical valuable characteristics of civilized community. In historical consciousness, therefore, the essence of civilized development, "a cultural matrix" of society..." [1, p. 201] is expressed. Cognition of this essence and identification of society and its atom - individual with this essence are also culture-congruent. The analysis of historical consciousness of this or that type of society provides guidance on ... "ways, typical for each type of culture, by means of which the social individual selfidentified in social time ..." [2, p. 58].

A lot of outstanding philosophers and sociologists accept and prove the statute of active nature of historical consciousness, focused, above all, on social practice and cultural identity ensuring involving cultural conditionality and close interrelation of all historical consciousness forms. Thus, interpretation of historical consciousness phenomenon by the largest foreign expert in the field of historical consciousness $Y$. Ryuzen is based on the thesis about its practical intentionality and cultural conformity. In this regard, realizing symbiotic relationship between rational origin of Modernism and irrational origin of Postmodernism, Ryuzen postulates the necessity of historical knowledge involving into the general concept of metahistory not only on the basis of "objectivity" (the analysis of sources as basis of historical experience), but also "narration". The philosopher understands cogitative patterns providing "correlation of cultural experience with cultural practice of collective memory and identity" as a narrative [5, p.24]. From the point of view of the scientist it is the narrative that makes the past experience actual to explain the present and to make the future possible. It provides a time continuum of the present, the past and the future and, therefore, historical identification of society in time, giving to its existence certain stability. Y. Ryuzen emphasized that he understands set of mental operations both cognitive and emotional, both conscious and unconscious as historical consciousness.

Not only Y. Ryuzen, but also other supporters of the concept of history subjectivity (existing, according to them, only within narrative reconstruction of historical process) consider that rules of this narrative, as well as history methodology, are set by the definite "historiographic tradition" which provides continuity of historical knowledge" [14, p. 15]. Therefore "methodological disputes make sense only in a certain tradition ..." [14, p. 20], founded, of course, by culture formed by historical process of national and state community.

Scientists state conditionality of historical science and philosophy of history by the common cultural determinants of mass historical consciousness making a matrix of historical memory and "growing", above all, on the basis of ordinary level of historical consciousness. It cannot be denied that historical and philosophical and historical theories play an acculturating role in relation to mass historical consciousness for the benefit of national security ensuring. They should not allow, above all, falsification of historical knowledge as the most important component of historical consciousness.

We consider thesis that theoretical, scientific level of historical consciousness plays the leading role in formation of national consciousness to be enough reasonable, on its basis there is "... a formation of authentic consciousness of people" [4, p. 241]. It is not surprising because the nation formation is connected with modernization processes, with formation of industrial society bases as a step of world historical process development, inconceivable without the leading, "acculturating" role of science in spiritual sphere of the life 
of society in relation to ordinary public consciousness.

At the level of the period before the appearance of national consciousness (consciousness of generation, tribe, nationality, people) existing within traditional society the ordinary historical consciousness which is in the social terms at the level of social psychology, mythological, connected with time, art and metaphoric reflection of the public relations of this social group predominates. As for its theoretical and political and ideological component, it showed itself in the form of conceptualization creation about the place and the role of ethnos or of the state education in history. However, it existed in the form of ideological, philosophical and historical or theological and historical works which are based on mythological, emotional and metaphoric, connected with time and connected with Providence conceptualizations of history. Not without reason the author of the dissertation research devoted to the features of historical consciousness of Russian people, states that "... one feature of historical consciousness of Russian people is its connection with national consciousness ..." and "... overloading by political and ideological components..." [10, p. 17]. The theorist emphasizes the people's awakening as a result of the Great Patriotic war of 1812 - the time of the beginning of the mature modernization processes contributing to the formation of Russia as the national and state community. Modern researchers of historical consciousness classification consider the rational interpretation of history originated during the Renaissance and realized its potential during the Modernism period, to be the main determinant of appearance of "historical consciousness in the proper sense of the term" [3, p. 83]. It is noted that historical science and general education on its basis contribute to the national consciousness formation [8, p. 10].

Therefore a lot of modern researchers raise the issue of strengthening of the role of historical science and philosophy of history in the fight against anti-cultural and non cultural manifestations of historical consciousness, which are based or rather parasitize, on such a fundamental characteristic of empirical, ordinary, social and psychological level of historical consciousness as mythologization. They are willingly learned by mass consciousness owing to their simplicity, emotional and metaphoric saturation, and primitive syncreticism.

The role of historical consciousness mythologization, however, is twofold. In this regard, it is rather interesting to consider correlation of historical memory which is usually treated as a phenomenon immanent to social and psychological component of historical consciousness and historical consciousness in general. The vast majority of researchers note that historical memory represents rather amorphous structure of historical consciousness which is at the level of empirical, ordinary social consciousness and possessing brightly expressed features of mythologization. Therefore, among its essential characteristics the following are added: the usage in primitive society, symbolization, mythologization [8, p. 3], personification through which understanding of value of historical events and phenomenon for modernity is carried out. Historical memory is fixed in such world outlook forms as legends, fairy tales, and traditions. The exaggeration of a role of separate historical events and heroes is peculiar to historical memory.

It is noteworthy that cultural identification is present in historical memory in the form of "ethnogenetic myth" including such elements as the myth of origin, the myth of the past, the myth of the territory, the myth about cultural heroes. All these myths are embodied in various texts and also in symbols and rituals, that is, in footholds of national culture. The defining role of archaic indeed historical memory creating the empirical level of mass historical consciousness is reflected, apparently, in the fact that it is responsible for preservation of valuable metahistorical constants defining stability of nation in historical time and historical space, fixing general valuable coordinates of other levels and forms of the national and state historical consciousness [17; 18]. 
Therefore, the ordinary level of historical consciousness producing culturally-based mythologization of mass historical consciousness has got a number of advantages concerning preservation and development of axiological metahistorical core of national and state community. This advantage is, apparently, that social psychology as a level of historical consciousness reproduces archetypes of historical memory conditioning historical stability of civilization [16; 17, p. 19]. The emotional and estimate essence of myth as the dominating form of ordinary historical consciousness, its archetypical component which defines cultural matrix of society, the main characteristics of cultural mythology allows to transfer moral imperatives by which national and state community goes, making essence of its cultural distinctness from the sphere of the limited by various available conditions of present by means of "rootedness" in the history into the aspect of due. And to transfer them in convenient and available to mass consciousness form, that is to create what $P$. Riker called "fair history" for the nation. Apparently, mythological structure determined by historical experience, traditions and, above all, metahistorical values, underlies the national idea as optimistic script of future development of society determining not only the main features of ordinary mass psychology, but also imperious decisions of ruling elite.

On the other hand, "man-made", artificial, acultural, introduced from the outside, mythologization of historical consciousness poses risks of the past distortion and various manipulative technologies application based on this distortion, because modern mythology represents, according to V.A. Terekhova "...the artificial propagandistic product created for the purpose of conscious introduction of manipulative ideas into the inhabitant consciousness" [12, p. 88]. These technologies can create a situation of society narrow-mindedness limiting it in freedom of choice of the best variant of solution of pressing problems and understanding of the existence in the world.

The purposeful mythologization of history poses the other risk. It can present a situation of vector choice of society development as absolute freedom, and it can draw equal and undetermined civilization alternatives. Thus, the danger of uncontrollable mythologization of historical consciousness is that society, under the influence of emotional and estimated components excessively emphasized by myth (including various phobias and stereotypes), can resist either archaization temptations of the present or modernization of the past. Archaization of the present can lead to the narrowing of nation futuristic horizon to the borders of realization of the past alternatives. Apparently, historical consciousness orientation only towards the present alternatives realization poses the greater risk because it breaks temporal continuity of national and state development. Therefore "the space of risk" for carrying out the transformations, which are not supported by cultural conformity and historical experience, is formed, creating the basis for voluntaristic decisions.

Besides, social mythologization can induce society to make sharp, unjustified by the set historical conditions, cultural turn. It can lead to the cultural trauma similar to that which our society endured at the beginning of formation of modern Russian nationhood. Both archaization and modernization of mythologized historical consciousness are capable to reduce spiritual potential of adequate response of national and state community to risks and challenges of modern world considerably and both of them represent national security threat. B.G. Mogilnitsky emphasizes that "the most important function of historical science consists in demythologization of social consciousness" [6, p. 49]. "Clarification" of acultural mythological components of historical consciousness on the basis of theoretical reflection of historical experience is an essential problem of scientific, theoretical component of historical consciousness and ideological constructs formed on its basis.

The way of overcoming of both types of historical consciousness distortion and, at the same time, minimization of risk of loss of cultural historical consciousness definiteness, fraught with loss of national sovereignty and society integration, perhaps, is "formality" (E. 
Giddens's formulation) of historical knowledge as basis of historical consciousness. Such formality is based on abstract and performative language features as the most important element of culture. It is considered that solutions of essential problem of historical consciousness formation alien to both cultural refinement and falsification on the basis of destructive mythologization, consist, above all, in popularization of historical science and philosophical and historical knowledge by means of colloquial, ordinary language and also in institutionalization of this process. The matter is that the power, social organizations and mass media, within the ideology based on formulation of metahistorical cultural constants, would acquire "the need of conscious institutional conditions in the course of public consciousness demythologization" [13, p. 33] on the basis of scientific achievements and rational philosophical and historical knowledge.

\section{Лumepamypa}

1. Банкерова Е.И. Историческое сознание в системе общественных отношений // Вестник Иркутского государственного технического университета. 2013. № 1 (72). С. 199-207.

2. Барг М.А. Историческое сознание как проблема историографии // Вопросы истории. 1982. № 12. С. 49-67.

3. Барг М.А. Категории и методы исторической науки. М.: Наука, 1984. 341 с.

4. Гобозов И.А. Введение в фрилософиюю истории. М.: Гуманитарное знание, 1993. $306 \mathrm{c}$.

5. Линченко А.А. Проблема исторического сознания в философии и теории истории Йорна Рюзена // Известия Саратовского университета. Серия Философия. Политология. Педагогика. 2015. Т. 15. Вып. 4. С. 22-27.

6. Могильницкий Б.Г. Историческое познание и историческое сознание // Историческая наука и историческое сознание / Под ред. Б.Г. Могильницкого. Томск, 2009. $230 \mathrm{c}$.

7. Путилова Е.Г. Историческое сознание и историческая память: соотношение понятий на современном этапе // Исторические, философрские, политические и юридические науки, культурология и искусствоведение. 2012. № 10-12. С. 143145.

8. Репина Л.П. Опыт социальных кризисов в исторической памяти // Кризисы переломных эпох в исторической памяти. 2012. С. 3-37.

9. Руденко А.М. Социовитальная концепция смысложизненной интенциональности экзистенции человека: Дис... док. фрилос. наук. Ростов-наДону, 2012. 374 с.

10. Свирида Н.Н. Историческое сознание как явление культуры: автореферат диссертации на соискание ученой степени кандидата философских наук. Омск, 2004. 18 c.

11. Сыров В.Н. В каком историческом сознании мы нуждаемся: к методологии подхода и практике использования // Вестник Томского государственного университета. История. 2013. №1 (21). С. 183-190.

12. Терехова B.A. Миф как парадигма общественного сознания // XXI век: будущее России в философском измерении: Материалы Второго российского философфского конгресса / 7-11 июня 1999 г. / в 2 т. Екатеринбург, 1999. Т.2. $242 \mathrm{c}$.

13. Федоровский А.П. Историческое сознание: особенности формирования и объективации // Вестник Адыгейского государственного университета. Серия1. Регионоведение: фрилософия, история, социология, юриспруденция, 
политология, культурология, 2011. № 3. С. 29-34.

14. Чистяков М.Н. Историческое сознание как специфический тип онтологии: к проблеме выделения инвариантов социальности // Вестник НГУ. Серия: Философия. 2010. Т.8. Выпуск 1. С. 15-21.

15. Шестаков Ю.А. Историческое сознание как фрактор стратегического противодействия угрозам национальной безопасности России // Гуманитарные и социальные науки. 2016. № 5. С. 58-69.

16. Финько М.В. Проблема межличностного общения и духовный кризис: культурологический анализ // Известия высших учебных заведений. СевероКавказский регион. Серия: Общественные науки. 2005. № 3. С. 9-14.

17. Shestakov Yu.A., Nesmeyanov E.E. L.P. Karsavin's historiosophy in the light of basic problems of Russian national security protection // Научный альманах стран Причерноморья. 2015. № 4 (4). С. 16-20.

18. Uznarodov D.I. The specifics of the internal migration processes in the North Caucasus in the post-soviet period // Научный альманах стран Причерноморья. 2016. № 2. http://science-almanac.ru

\section{References}

1. Bankerova E.I. Istoricheskoe soznanie $\mathrm{v}$ sisteme obshchestvennykh otnoshenii [Historical consciousness in the system of public relations]. Vestnik Irkutskogo gosudarstvennogo tekhnicheskogo universiteta [Bulletin of Irkutsk state technical university] 2013. no.1 (72). pp. 199-207 (in Russian).

2. Barg M.A. Istoricheskoe soznanie kak problema istoriografii [Historical consciousness as historiography problem] Voprosy istorii [History questions] 1982. No.12. pp. 49-67 (in Russian).

3. Barg M.A. Kategorii i metody istoricheskoi nauki [Categories and methods of historical science] Nauka [Science]. Moscow,1984. 341 p.

4. Gobozov I.A. Vvedenie v filosofiiu istorii [Introduction to history philosophy]. Moscow: Gumanitarnoe znanie [Humanitarian knowledge], 1993. 306 p. (in Russian).

5. Linchenko A.A. Problema istoricheskogo soznaniia $\vee$ filosofii $\mathrm{i}$ teorii istorii lorna Riuzena [The problem of historical consciousness in philosophy and Y. Ryuzen`s history theory] Izvestiia Saratovskogo universiteta [Proceedings of Saratov university]. Seriia Filosofiia. Politologiia. Pedagogika [Philosophy edition. Political science. Pedagogics]. 2015. Vol. 15. I. 4. pp. 22-27 (in Russian).

6. Mogilnitsky B.G. Istoricheskoe poznanie i istoricheskoe soznanie. Istoricheskaia nauka i istoricheskoe soznanie [Historical knowledge and historical consciousness. Historical science and historical consciousness]. Under the editorship of B.G. Mogilnitsky. Tomsk, 2009. 230 p. (in Russian).

7. Putilova E.G. Istoricheskoe soznanie i istoricheskaia pamiat': sootnoshenie poniatii na sovremennom etape [Historical consciousness and historical memory: correlation of concepts at the present stage] Istoricheskie, filosofskie, politicheskie i iuridicheskie nauki, kul'turologiia i iskusstvovedenie [Historical, philosophical, political and legal sciences, cultural science and art criticism]. 2012. No. 10-12. 143-145 p. (in Russian).

8. Repina L.P. Opyt sotsial'nykh krizisov $\mathrm{v}$ istoricheskoi pamiati. Krizisy perelomnykh epokh $v$ istoricheskoi pamiati [Experience of social crises in historical memory. Crises of critical epochs in historical memory]. 2012. pp. 3-37 (in Russian).

9. Rudenko A.M. Sotsiovital'naia kontseptsiia smyslozhiznennoi intentsional'nosti ekzistentsii cheloveka [Social and vital concept of life-purpose intentionality of man 
existence]. Dissertation of Dr. phil. Rostov-on-Don. 2012. 374 p. (in Russian).

10. Svirida N.N. Istoricheskoe soznanie kak iavlenie kul'tury [Historical consciousness as culture phenomenon] avtoreferat dissertatsii na soiskanie uchenoi stepeni kandidata filosofskikh nauk [Candidate`s Diss.]. Omsk, 2004. 18 p. (in Russian).

11. Syrov V.N. V kakom istoricheskom soznanii my nuzhdaemsia: k metodologii podkhoda i praktike ispol'zovaniia [What historical consciousness we need: to methodology of approach and practice of use]. Vestnik Tomskogo gosudarstvennogo universiteta [Bulletin of Tomsk state university]. Istoriia [History]. 2013. No. 1 (21). pp. 183-190 (in Russian).

12. Terekhova V.A. Mif kak paradigma obshchestvennogo soznaniia [Myth as paradigm of public consciousness]. XXI vek: budushchee Rossii v filosofskom izmerenii: Materialy Vtorogo rossiiskogo filosofskogo kongressa [The 21st century: Russian future in philosophical dimension: proceedings of the Second Russian philosophical congress] on June 7-11, 1999 / in 2 V. Yekaterinburg. 1999. Vol. 2. 242 p. (in Russian).

13. Fedorovsky A.P. Istoricheskoe soznanie: osobennosti formirovaniia i ob"ektivatsii [Historical consciousness: features of formation and objectivization]. Vestnik Adygeiskogo gosudarstvennogo universiteta [Bulletin of Adygei state university]. Seriia1. Regionovedenie: filosofiia, istoriia, sotsiologiia, iurisprudentsiia, politologiia, kul'turologiia [Edition 1. Regional studies: philosophy, history, social science, legal science, political science, cultural science]. 2011. No. 3. pp. 29-34 (in Russian).

14. Chistyakov M.N. Istoricheskoe soznanie kak spetsificheskii tip ontologii: k probleme vydeleniia invariantov sotsial'nosti [Historical consciousness as specific type of ontology: to the problem of allocation of sociality invariants]. Vestnik NGU Seriia: Filosofiia [Bulletin of NSU. Edition: Philosophy]. 2010. Vol. 8. I. 1. pp. 15-21 (in Russian).

15. Shestakov Yu.A. Istoricheskoe soznanie kak faktor strategicheskogo protivodeistviia ugrozam natsional'noi bezopasnosti Rossii [Historical consciousness as a factor of strategic counteraction to threats of national security of Russia]. Gumanitarnye i sotsial'nye nauki [Humanitarian and social sciences]. 2016. No. 5. pp. 58-69 (in Russian).

16. Finko M.V. Problema mezhlichnostnogo obshcheniia i dukhovnyi krizis: kul'turologicheskii analiz [The problem of interpersonal communication and spiritual crisis: culturological analysis]. Izvestiia vysshikh uchebnykh zavedenii. SeveroKavkazskii region] Proceedings of higher educational institutions. The North Caucasus region. Seriia: Obshchestvennye nauki [Edition: Social sciences]. 2005. No. 3. pp. 9-14 (in Russian).

17. Shestakov Yu.A., Nesmeyanov E.E. L.P. Karsavin's historiosophy in the light of basic problems of Russian national security protection. Science almanac of Black Sea region countries. 2015. №. 4 (4). pp. 16-20.

18. Uznarodov D.I. The specifics of the internal migration processes in the North Caucasus in the post-soviet period. Science almanac of Black Sea region countries. 2016. No. 2. Available at: http://science-almanac.ru 